\title{
L-Carnitine Supplementation During Hepatitis C Virus Treatment with Sofosbuvir/Daclatasvir Plus Ribavirin: Effect on Anemia: A Pilot Study
}

\author{
LOBNA ABO ALI, M.D.*; SAMAH ELSHWEIKH, M.D.** and SHIMAA SAIED, M.D.*** \\ The Departments of Tropical Medicine*, Internal Medicine** and Public Health \& Community Medicine***, Faculty of Medicine, \\ Tanta University, Tanta, Egypt
}

\begin{abstract}
Background: In the direct acting antiviral era, the role of ribavirin (RBV) in the treatment of hepatitis c virus (HCV) remains crucial, especially in patients with liver cirrhosis and treatment experienced patients. L-carnitine was reported to improve anemia in patients with HCV treated with interferon alone or with ribavirin.
\end{abstract}

Aim of Study: To evaluate the effect of L-carnitine on improving ribavirin induced hemolytic anemia in patients with $\mathrm{HCV}$ treated with sofosbuvir/daclatasvir plus ribavirin (SOF/DCV/RBV).

Patients and Methods: Naive patients with HCV related liver cirrhosis and treatment experienced patients who received prior interferon therapy were randomized to receive either $\mathrm{SOF} / \mathrm{DCV} / \mathrm{RBV}$ plus L-carnitine $(\mathrm{n}=49$ ) or SOF/DCV/RBV $(n=49)$ for 12 weeks as a control group. Changes in hemoglobin concentration, reduction of ribavirin dose and its effect on sustained virological response (SVR) were evaluated.

Results: After 4 and 12 weeks of treatment, the hemoglobin concentration was significantly higher in the L-carnitine group than in the control group $(p<0.001)$. RBV dose was reduced in $10.2 \%$ of patients in the L-carnitine group versus $22.5 \%$ in the control group. The adherence of patients to their ribavirin dose was higher in patients treated with L-carnitine than patients in the control group $(89.8 \%$ vs. $77.5 \%)$. SVR 12 rate in the L-carnitine group was higher than that in the control group $(93.9 \% \%$ vs. $87.8 \%)$.

Conclusion: L-carnitine is effective in improving hemolytic anemia induced by ribavirin in patients treated for hepatitis $\mathrm{C}$ virus and increase patient's adherence to treatment that guarantees the best opportunity to achieve an SVR.

Key Words: Hepatitis C virus - L-carnitine - Ribavirin.

\section{Introduction}

THE highest prevalence of hepatitis C virus (HCV) infection in the world is found in Egypt [1] with

Correspondence to: Dr. Lobna Abo Ali

E-Mail: lobna fahmy@yahoo.com more than $90 \%$ of all infections reported to be $\mathrm{HCV}$ genotype 4 [2]. The success of HCV treatment leads to a significant decrease in the risk of complications related to HCV, such as hepatic decompensation and hepatocellular carcinoma [3] .

The direct-acting antiviral agents (DAA) regimens of HCV treatment have significantly improved sustained viral response (SVR) rates in previously treated and treatment naive patients with HCV genotype 4 [4]. In the DAA era, the role of ribavirin (RBV) with DAA regimens was expected to be eliminated. On the contrary, the role of RBV in the treatment of HCV remains crucial, especially in patients with liver cirrhosis and treatment experienced patients [5].

In regimens containing $\mathrm{RBV}$, most side effects were related to hemolytic anemia induced by ribavirin, which requires dose reduction or discontinuation and compromises treatment response. It is necessary to improve the response rate and decrease the relapse rate [6]

L-carnitine is synthesized by the liver, kidney and brain from the amino acids methionine and lysine, but is obtained mainly from animal sources such as meat and dairy products [7]. It plays an important role in the production of cellular energy

\footnotetext{
Abbreviations:

CTP : Child-Turcotte-Pugh.

DAA : Direct-acting antiviral agents.

DCV : Daclatasvir

$\mathrm{HCV}$ : Hepatitis C virus.

Peg-IFN : Pegylated interferon.

PCR : Polymerase chain reaction.

RBV : Ribavirin.

SOF : Sofosbuvir

SVR : Sustained virological respons.
} 
[8], since it participates in the transport of longchain fatty acids to the mitochondrial matrix for beta oxidation [9]. In addition, it has a role in suppressing apoptosis and improving the function of bone marrow progenitors by increasing the number of colony forming units [10].

In patients with $\mathrm{HCV}$ treated with interferon alone or with ribavirin, supplementation with Lcarnitine was reported to improve anemia, leucopenia and thrombocytopenia [10]

This study aimed to evaluate the effect of Lcarnitine on improving ribavirin induced hemolytic anemia in patients with hepatitis $\mathrm{C}$ virus treated with sofosbuvir/daclatasvir plus ribavirin.

\section{Patients and Methods}

\section{Study design and patients:}

This was a prospective, randomized, controlled, open label pilot study conducted in Egypt. The patients had been recruited from the Department of Tropical Medicine and Infectious diseases and Department of Internal Medicine, Tanta University Hospital from May 2016.

The included patients were randomized using a computerized random number generator with a block size of four and an equal allocation ratio. To ensure allocation concealment, sequentially numbered, opaque and sealed envelopes were used.

Patients were randomized to receive either daily oral sofosbuvir (SOF) 400mg, daclatasvir (DCV) 60mg, RBV 1000-1200mg plus L-carnitine $1.5 \mathrm{gm}$ or SOF $400 \mathrm{mg}$, DCV $60 \mathrm{mg}$ and RBV $1000-1200 \mathrm{mg}$ for 12 weeks. Weight based RBV 1000 or $1200 \mathrm{mg} /$ day if it is $<75$ or $\geq 75 \mathrm{~kg}$ body weight, respectively. In patients with Child-Pugh B decompensated cirrhosis, ribavirin started at the dose of $600 \mathrm{mg}$ daily and the subsequent doses adjusted depending on tolerance. Treatment decision was given according to according to the protocol of Egyptian $\mathrm{Na}$ tional Committee for Controlling HCV and EASL recommendations on treatment of hepatitis C, 2015 [4].

Eligible patients were naive patients with liver cirrhosis Child-Pugh score $\leq 8$; and treatmentexperienced patients who received prior interferon therapy with positive polymerase chain reaction (PCR) for HCV-RNA.

Exclusion criteria were patients with hepatitis B or human immunodeficiençy virus co-infection, platelets less than $50,000 / \mathrm{mm}$, hemoglobin $<12 \mathrm{gm} /$ $\mathrm{dl}$ in females and $<13 \mathrm{gm} / \mathrm{dl}$ in males, uncontrolled diabetes mellitus (Hb A1C) $>9 \%$, hepatocellular carcinoma or extra-hepatic malignancy, pregnancy, lactation, severe cardiac, pulmonary, or renal diseases.

A written informed consent was signed by every patient before enrolment in the study. The study was approved by the Ethics Committee of the Faculty of Medicine, Tanta University. All authors had access to the study data, and reviewed and approved the final manuscript.

\section{Assessments:}

Baseline evaluation included clinical examination, laboratory tests including complete blood picture, aspartate transaminase, alanine transaminase, serum bilirubin, serum albumin, and international normalized ratio, serum creatinine, $\mathrm{HBsAg}$, $\mathrm{Hb} \mathrm{A} 1 \mathrm{C}$, alpha fetoprotein, quantitative HCV RNA and abdominal ultrasound. Estimation of $\mathrm{HCV}$ RNA level was done by Cobas Ampli Prep/Cobas TaqMan HCV-RNA assay (Roche Diagnostics; Pleasanton, CA, USA) with a threshold of detection $15 \mathrm{IU} / \mathrm{mL}$. Liver cirrhosis was diagnosed on the basis of clinical, laboratory findings, abdominal ultrasound, fibroscan and Fibrosis-4 (FIB-4) score $>3.25$. Child-Turcotte- Pugh (CTP) was calculated based on its respective formula.

The treated patients were followed-up at week 4 and 12 weeks of the treatment. At each visit the following was done: Clinical assessment of the patients and reviewing the results of laboratory tests complete blood picture, liver and kidney profile. Quantitative real-time PCR for HCV RNA was done at 12 weeks post-treatment to confirm SVR.

\section{Outcomes:}

The primary outcome of the trial was the difference in the level of hemoglobin concentration between the two study groups at the end of 12 weeks of treatment.

\section{Statistical analysis:}

The statistical data are reported as the mean \pm standard deviation (SD), median (interquartile range), frequencies (number) and percentages when appropriate. A comparison of numerical variables between the study groups was performed using Student's $t$-test to compare independent samples from two groups when the samples were normally distributed and the Mann-Whitney U-test was used to compare independent samples when the samples were not normally distributed. To compare categorical data, chi square test was performed. Values of $p$ less than 0.05 (two-tailed) were considered 
statistically significant. All statistical calculations were performed using the computer program SPSS (Statistical Package for the Social Science; SPSS, Chicago, Illinois, USA) version15 for Microsoft Windows.

\section{Results}

A total of 143 naive patients with HCV related liver cirrhosis and treatment experienced patients who received prior interferon therapy were screened for participation in this study. Out of whom 45 patients were excluded thus, 98 patients were enrolled and randomly assigned to receive either $\mathrm{SOF} / \mathrm{DCV} / \mathrm{RBV}$ plus L-carnitine $(\mathrm{n}=49)$ or $\mathrm{SOF} /$ $\mathrm{DCV} / \mathrm{RBV}(\mathrm{n}=49)$ as a control group for 12 weeks (Fig. 1).

The baseline characteristics of patients of the studied groups were summarized in Table (1). There was no significant difference in baseline variables between the groups.

In patients receiving L-carnitine, the mean hemoglobin concentration showed no significant differences after 4 weeks $(12.79 \pm 2.92)$ and 12 weeks $(13.14 \pm 2.63)$ of treatment when compared to baseline level $(14.06 \pm 1.43)(p>0.05)$. In the control group, hemoglobin concentration was significantly decreased from (13.91 \pm 1.19$)$ at baseline to $(11.46 \pm 1.84)$ after 4 weeks and to $(10.98 \pm 1.26)$ after 12 weeks of treatment $(p<0.001)$.

In the L-carnitine group, hemoglobin concentration was significantly higher than in the control group after 4 weeks of treatment $(12.79 \pm 2.92)$ vs. $(11.46 \pm 1.84)$ respectively. Also, after 12 weeks of treatment the mean hemoglobin concentration was significantly higher in patients treated with Lcarnitine when compared to the control group $(13.14 \pm 2.63)$ vs. $(10.98 \pm 1.26)(p<0.001)$ (Table 2).

RBV dose was reduced in 5 patients $(10.2 \%)$ in the L-carnitine group compared with 11 patients $(22.5 \%)$ in the control group. The adherence of patients to their ribavirin dose was higher in patients treated with L-carnitine than patients in the control group $(89.8 \%$ vs. $77.5 \%)$.

A total of $90.8 \%$ of all patients achieved SVR12. SVR12 was $86.9 \%$ and $92 \%$ in treatment experienced patients and in naive cirrhotic patients, respectively.

Three patients (6.1\%) in the L-carnitine group could not achieve SVR12 compared to six patients $(12.2 \%)$ in the control group. As a result, SVR12 rate in the L-carnitine group was higher than that in the control group (93.9\% vs. $87.8 \%$ ).

Table (1): Patient baseline characteristics.

\begin{tabular}{|c|c|c|c|}
\hline & $\begin{array}{c}\text { SOF/DCV/RB V+L-carnitine } \\
\text { (L-carnitine Group) } \\
n=49\end{array}$ & $\begin{array}{c}\text { SOF/DCV/RBV } \\
\text { (Control Group) } \\
n=49\end{array}$ & $p$-value \\
\hline Age, year, mean (SD) & $52.27 \pm 9.85$ & $55.06 \pm 7.12$ & 0.224 \\
\hline Sex, male, $\mathrm{n} \%$ & $27(55.1)$ & $31(63.3)$ & 0.713 \\
\hline White blood cell, $10^{9} / \mathrm{L}$, mean (SD) & $6.43 \pm 2.54$ & $5.53 \pm 1.55$ & 0.228 \\
\hline Hemoglobin (g/dL), Median (IQR) & $13.9(13-15.07)$ & $13.8(13-14.83)$ & 0.820 \\
\hline Platelet count, $10^{9} / \mathrm{L}$, Median (IQR) & $199(128.5-236)$ & $177(143.25-252.75)$ & 0.392 \\
\hline INR, Median (IQR) & $1.1(1-1.2)$ & $1.1(1-1.3)$ & 0.746 \\
\hline Aspartate aminotransferase (IU/L), Median (IQR) & $42(22.75-61)$ & $48(29.5-74)$ & 0.121 \\
\hline Alanine aminotransferase (IU/L), Median (IQR) & $47(30.5-76)$ & $41(23-70)$ & 0.316 \\
\hline Albumin, g/dl, Median (IQR) & $4(3.4-4)$ & $4(3.3-4.13)$ & 0.105 \\
\hline Total-bilirubin (mg/dL), Median (IQR), & $0.93(0.63-1.26)$ & $0.9(0.7-1.2)$ & 0.621 \\
\hline HCV RNA, $\log 10 \mathrm{IU} / \mathrm{ml}$, Median (IQR) & $5.62(4.32-6.08)$ & $5.41(4.74-5.63)$ & 0.865 \\
\hline $\begin{array}{l}\text { Child-Pugh class, } n(\%) \text { : } \\
\text { A } \\
\text { B }\end{array}$ & $\begin{array}{l}30(61.2) \\
6(12.2)\end{array}$ & $\begin{array}{l}32(65.3) \\
7(14.3)\end{array}$ & 0.989 \\
\hline $\begin{array}{l}\text { Prior HCV treatment, } n(\%) \text { : } \\
\text { Treatment naive } \\
\text { Treatment-experienced }\end{array}$ & $\begin{array}{l}36(73.5) \\
13(26.5)\end{array}$ & $\begin{array}{l}39(79.6) \\
10(20.4)\end{array}$ & 0.774 \\
\hline $\begin{array}{l}\text { DCV : Daclatasvir. } \\
\text { HCV : Hepatitis C virus. } \\
\text { INR : International normalized ratio. } \\
\text { IQR : Interquartile range. }\end{array}$ & $\begin{array}{l}\text { : Ribavirin. } \\
\text { : Standard deviation. } \\
\text { Sofosbuvir. }\end{array}$ & & \\
\hline
\end{tabular}


Table (2): Hemoglobin concentration in the studied group at baseline, after 4 and 12 weeks of treatment.

\begin{tabular}{|c|c|c|c|c|c|c|}
\hline & \multicolumn{3}{|c|}{$\begin{array}{c}\mathrm{S} \mathrm{OF} / \mathrm{DC} \mathrm{V} / \mathrm{RB} \mathrm{V}+\mathrm{L}-\mathrm{c} \text { arnitine } \\
\text { (L-carnitine Group) } \\
\mathrm{n}=49\end{array}$} & \multicolumn{3}{|c|}{$\begin{array}{c}\mathrm{SOF} / \mathrm{DCV} / \mathrm{RBV} \\
\text { (Control Group) } \\
\mathrm{n}=49\end{array}$} \\
\hline & Before treatment & After 4 weeks & After 12 weeks & Before treatment & After 4 weeks & After 12 weeks \\
\hline Hemoglobin (g/dL) & $14.06 \pm 1.43$ & $12.79 \pm 2.92 \mathbf{b}$ & $13.14 \pm 2.63 \mathbf{c}$ & $13.91 \pm 1.19$ & $11.46 \pm 1.84 \mathbf{a}, \mathbf{b}$ & $10.98 \pm 1.26 \mathbf{a}, \mathbf{c}$ \\
\hline $\begin{array}{l}\mathbf{a}_{p}<0.001 \text { : Comparison } \\
b_{p}<0.001 \text { : Groups L-ca } \\
c_{p<0.001: \text { Groups L-ca }}\end{array}$ & $\begin{array}{l}\text { within control group } \\
\text { rnitine vs control afte } \\
\text { mitine vs control after }\end{array}$ & $\begin{array}{l}4 \text { weeks of treat } \\
12 \text { weeks of trea }\end{array}$ & $\begin{array}{l}2 \text { we } \\
\text { int. } \\
\text { ent. }\end{array}$ & $\begin{array}{l}\mathrm{DC} \\
\mathrm{RB} \\
\mathrm{SO}\end{array}$ & $\begin{array}{l}\text { VV : Daclatasvir. } \\
\text { BV : Ribavirin. } \\
F \text { : Sofosbuvir. }\end{array}$ & \\
\hline
\end{tabular}

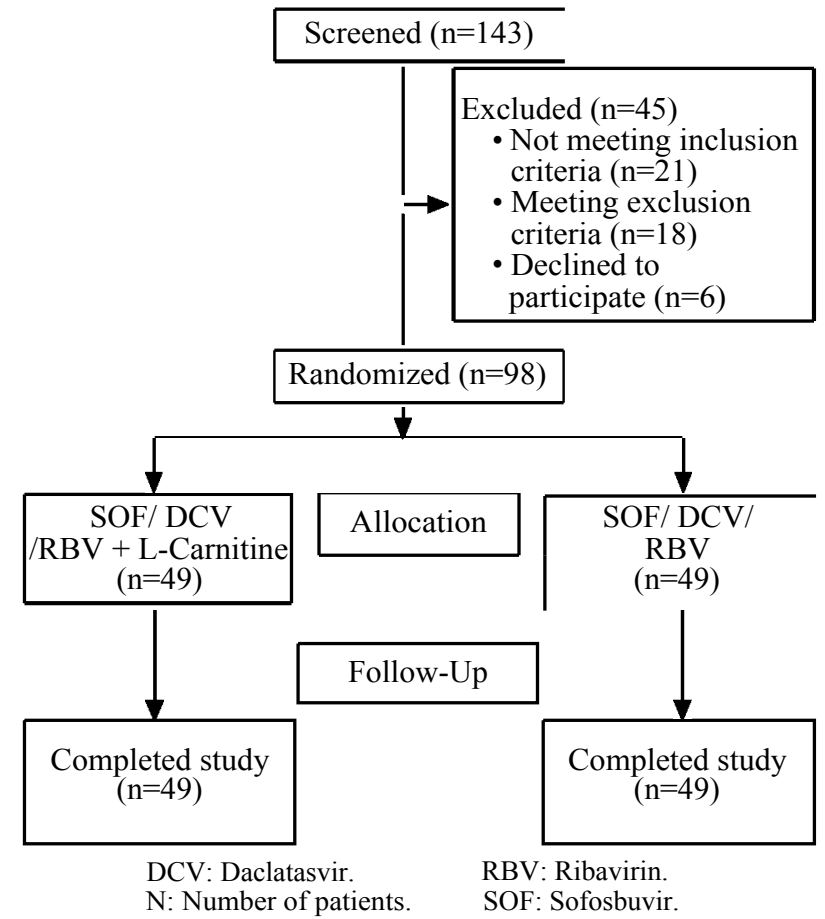

Fig. (1): Study flow chart.

\section{Discussion}

In Egypt, HCV infection is the most common cause of chronic liver diseases. The main complication in patients infected with HCV treated with a regimen containing RBV is hemolytic anemia [11]. It is recommended to discontinue or reduce RBV dose in patients who developed hemolytic anemia [12]. It has been reported that supplementation with L-carnitine improves hemoglobin levels in patients with $\mathrm{HCV}$ treated with pegylated interferon (Peg-IFN) plus ribavirin and in patients with renal insufficiency $[\mathbf{1 0 , 1 3 , 1 4 ]}$.

This study aimed to evaluate the effect of Lcarnitine on improving ribavirin induced hemolytic anemia in patients with hepatitis $\mathrm{C}$ virus treated with sofosbuvir/daclatasvir plus ribavirin.

In the current study, hemoglobin concentration was significantly decreased after 4 and to 12 weeks of treatment in patients treated with SOF/DCV /RBV, when compared to baseline. Decreased hemoglobin levels represent the main side effect of the RBV containing regimens. In a recent study, $14 \%$ of treated patients with SOF/DCV/RBV for 12 weeks developed anemia [15]. In another study, Salama et al., 2016 [16] reported that $45 \%$ of patients on SOF/DCV/RBV regimen experienced hemoglobin reduction $<12 \mathrm{~g} / \mathrm{dL}$ compared to pre-treatment levels.

Anemia may manifest itself in the first weeks of treatment with RBV and may continue during therapy [17] by reducing the survival of red blood cells [18]. Hemolytic anemia is likely to be related to the extensive accumulation of RBV in the red blood cells which leads to oxidative membrane damage and extravascular hemolysis by the reticuloendothelial system [19]

In this study, we observed a significantly greater decrease in hemoglobin level in the SOF/DCV/ RBV group than the SOF/DCV/RBV plus Lcarnitine group which indicates that supplementation with L-carnitine can improve hemolytic anemia induced by RBV.

This was in agreement with Malaguarnera et al., 2011 [10] who detected a significant decrease in hemoglobin concentration after 6 and 12 months of treatment of $\mathrm{HCV}$ patients with Peg-IFN- $\alpha 2 b$ plus RBV as compared to patients receiving PegIFN- $\alpha 2 b$, ribavirin plus L-carnitine.

The efficacy of L-carnitine in hemolytic anemia induced by RBV in patients with chronic $\mathrm{HCV}$ infection treated with DAA regimen plus RBV is probably due to the fact that L-carnitine protects red blood cells from oxidative stress and stabilizes their membranes, which increases the erythrocytes [20-22] . In addition, it has been suggested that Lcarnitine can act through the suppression of apoptosis and improvement of the function of bone marrow progenitors by increasing the number of colony forming units [10]. 
It was reported that L-carnitine increases the efficacy of erythropoietin in patients with impaired renal function in whom accelerated degradation of serum erythropoietin leads to anemia [19]. Also, in patients with thalassemia, the blood transfusion interval increased significantly after supplementation with L-carnitine [23].

We recorded a reduction of $\mathrm{RBV}$ dose in (10.2\%) of patients in the L-carnitine group, compared with $(22.5 \%)$ of patients in the control group and the adherence of patients to their ribavirin dose was higher in patients treated with L-carnitine than patients in the control group $(89.8 \%$ vs. $77.5 \%$ ). In a cohort of 551 patients with $\mathrm{HCV}$ related cirrhosis treated with SOF/DCV/RBV [28] the most common adverse events was anemia ( $3 \%$ and $31.3 \%$ ) resulted in a RBV dose reduction in (4\% and $33 \%$ ) of patients, in CTP-A and CTP-B; respectively [24].

In our study, SVR 12 was improved in the Lcarnitine group versus the control group (93.9\% vs. $87.8 \%$ ) respectively. Malaguarnera et al., 2011 [10] reported a significant improvement of SVR in patients receiving Peg-IFN- $\alpha$ 2b/RBV plus Lcarnitine for 12 months when compared to patients receiving Peg-IFN- $\alpha$ and RBV in 15 vs 7 patients (50\% vs $25 \%$ ) respectively. The treatment with Lcarnitine could be beneficial in treatment of $\mathrm{HCV}$ patients.

\section{Conclusion:}

L-carnitine is effective in improving hemolytic anemia induced by ribavirin in patients treated for hepatitis $C$ virus and increase patient's adherence to treatment that guarantees the best opportunity to achieve an SVR.

There are limitations in this study being a pilot study with a small number of patients.

\section{Financial support and sponsorship:}

Nil.

\section{Conflicts of interest:}

There are no conflicts of interest.

\section{References}

1- DORE G.J., WARD J. and THURSZ M.: Hepatitis C disease burden and strategies to manage the burden. J. Viral Hepat, 21: 1-4. http://dx.doi.org/10.1111/jvh.12253, 2014.

2- GUERRA J., GARENNE M., MOHAMED M.K. and FONTANET A.: HCV burden of infection in Egypt: Results from a nationwide survey. J. Viral Hepat, 19 (8): 560-567, 2012.
3- THOMAS D.L.: Global control of hepatitis C: Where challenge meets opportunity. Nat. Med., 19: 850-858, 2013.

4- EASL recommendations on treatment of hepatitis C 2015. J. Hepatol., 63: 199-236, 2015.

5- FELD J.J., JACOBSON I.M., SULKOWSKI M.S., et al. Ribavirin revisited in the era of direct-acting antiviral therapy for hepatitis $\mathrm{C}$ virus infection. Liver Int., 37 (1): 5-18, 2017.

6- DAVID R. NELSON, et al.: All-oral 12-week treatment with daclatasvir plus sofosbuvir in patients with hepatitis C virus genotype 3 infection: ALLY-3 phase III study. Hepatology, 61.4: 1127-1135, 2015.

7- FLANAGAN J.L., SIMMONS P.A. and VEHIGE J., et al.: Role of carnitine in disease. Nutr. Metab. (Lond), 16; (7): 30, 2010

8- MALAGUARNERA M.: Carnitine derivatives: Clinical usefulness. Curr Opin Gastroenterol., 28 (2): 166-76, 2012.

9- MALAGUARNERA M., VACANTE M., BERTINO G., NERI S., MALAGUARNERA M., GARGANTE M.P., et al.: The supplementation of acetyl-L-carnitine decreases fatigue and increases quality of life in patients with hepatitis $\mathrm{C}$ treated with pegylated interferon-alpha $2 \mathrm{~b}$ plus ribavirin. J. Interferon Cytokine Res., 31 (9): 653 9, 2011.

10- MALAGUARNERA M., VACANTE M., GIORDANO M., MOTTA M., BERTINO G., PENNISI M., et al.: Lcarnitine supplementation improves hematological pattern in patients affected by HCV treated with Peg interferonalpha 2 b plus ribavirin. World J. Gastroenterol., 17 (39): 4414-20, 2011.

11- De FRANCESCHI L., FATTOVICH G., TURRINI F., AYI K., BRUGNARA C., MANZATO F., et al.: Hemolytic anemia induced by ribavirin therapy in patients with chronic hepatitis $\mathrm{C}$ virus infection: Role of membrane oxidative damage. Hepatology, 31: 997-1004, 2000.

12- HADZIYANNIS S.J., SETTE H. Jr., MORGAN T.R., BALAN V., DIAGO M., MARCELLIN P., et al.: Peginterferon-alpha2a and ribavirin combination therapy in chronic hepatitis $\mathrm{C}$ : a randomized study of treatment duration and ribavirin dose. Ann. Intern. Med., 140: 346-355, 2004

13- HUROT J.M., CUCHERAT M., HAUGH M. and FOUQUE D.: Effects of L-carnitine supplementation in maintenance hemodialysis patients: a systematic review. J. Am. Soc. Nephrol., 13: 708-714, 2002.

14- MATSUMOTO Y., AMANO I., HIROSE S., TSURUTA Y., HARA S., MURATA M., et al.: Effects of L-carnitine supplementation on renal anemia in poor responders to erythropoietin. Blood Purif, 19: 24-32, 2001.

15- ABDEL-MONEIM A., ABOUD A., ABDEL-GABAAR M., ZANATY M.I. and RAMADAN M.: Efficacy and safety of sofosbuvir plus daclatasvir with or without ribavirin: Large real-life results of patients with chronic hepatitis C genotype 4. Hepatology International, 12: 348-355, 2018.

16- SALAMA H., ZEKRI A., MEDHAT E., ZAKARIA Z., SHOUSHA H., ALIM S.A., et al.: Sofosbuvir plus daklatasvir with fixed versus weight adjusted dose of ribavirin for treatment of HCV, genotype 4 among Egyptian patients. 
EC Gastroenterology and Digestive System, 1.5: 143153, 2016.

17- BARBARO G., Di LORENZO G., BELLONI G., FERRARI L., PAIANO A., DEL POGGIO P., et al.: Interferon alpha-2B and ribavirin in combination for patients with chronic hepatitis $\mathrm{C}$ who failed to respond to, or relapsed after, interferon alpha therapy: A randomized trial. Am. J. Med., 107: 112-118, 1999.

18- REUTER S.E., FAULL R.J., RANIERI E. and EVANS A.M.: Endogenous plasma carnitine pool composition and response to erythropoietin treatment in chronic haemodialysis patients. Nephrol. Dial Transplant, 24: 990-996, 2009.

19- Di FAZIO I., MOTTA M., MUSUMECI S., NERI S., PISTONE G. and MALAGUARNERA M.: Efficacy of human recombinant erythropoietin plus IFN-alpha in patients affected by chronic hepatitis C. J. Interferon Cytokine Res., 24: 594-599, 2004.

20- YEILIPEK M.A. and YEIN O.: Interferon-alpha therapy for refractory idiopathic thrombocytopenic purpura in children. Turk J. Pediatr., 39: 173-176, 1997.

21- PALMIERI L., RONCA F., MALENGO S. and BERTELLI A.: Protection of beta-thalassaemic erythrocytes from oxidative stress by propionyl carnitine. Int. J. Tissue React, 16: 121-129, 1994.

22- MERAL A., TUNCEL P., SÜRMEN-GÜR E., OZBEK R., OZTÜRK E. and GÜNAY U.: Lipid peroxidation and antioxidant status in beta-thalassemia. Pediatr. Hematol. Oncol., 17: 687-693, 2000.

23- EL-BESHLAWY A., EL ACCAOUI R., ABD ELSATTAR M., GAMAL EL-DEEN M.H., YOUSSRY I., SHAHEEN N., HAMDY M., EL-GHAMRAWY M. and TAHER A.: Effect of L-carnitine on the physical fitness of thalassemic patients. Ann. Hematol., 86: 31-34, 2007.

24- EL-KHAYAT H., FOUAD Y., MOHAMED H.I., et al.: Sofosbuvir plus daclatasvir with or without ribavirin in 551 patients with hepatitis C-related cirrhosis, genotype 4. Aliment Pharmacol. Ther., 47: 674-9, 2018.

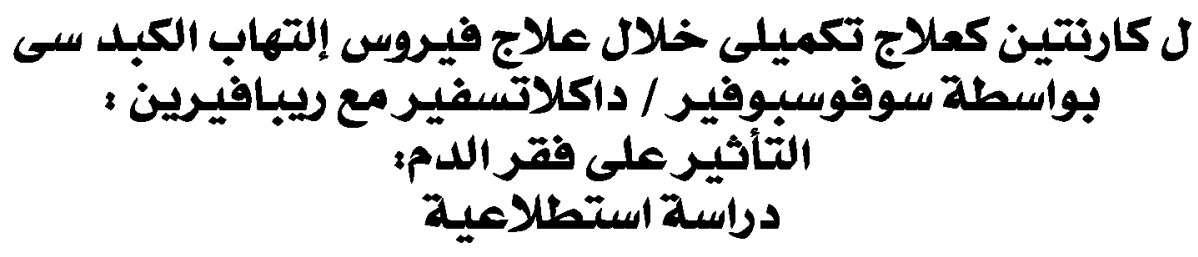

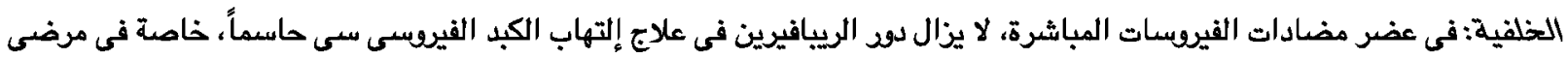

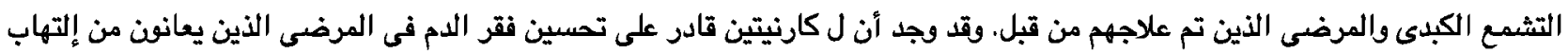

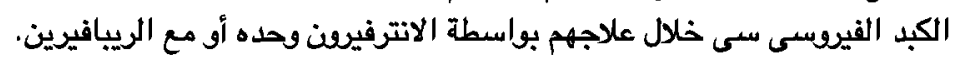

الغرض من البحث: تقييم تأثير ل كارنيتين على تحسين فقر الدم الانحلالى الناجم عن الريبافيرين خلال علاج فيرس إلتهاب الكبد سى بواسطة سوفوسبوفير / داكلاتسفير مع ريبافيرين.

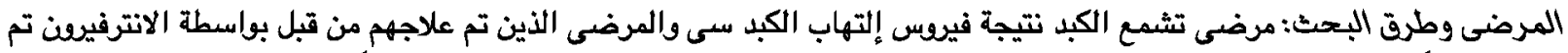

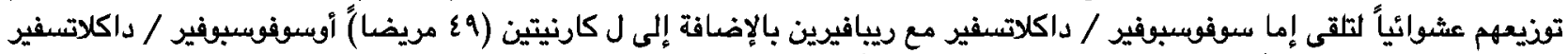

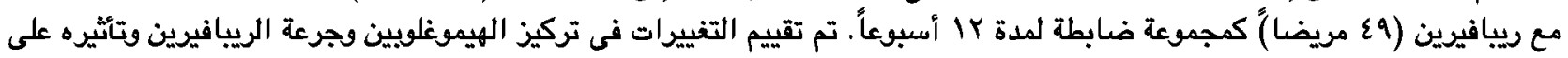
الاستجابة الفيروسية المستمرة.

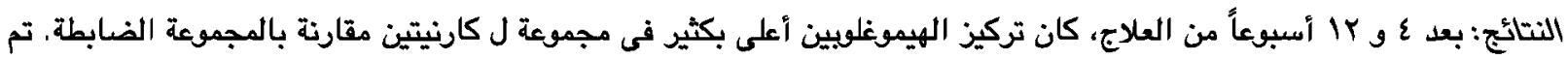

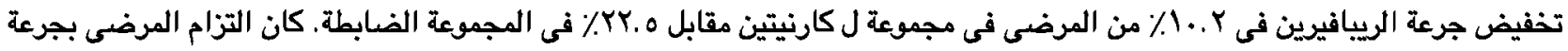

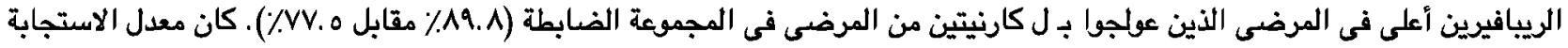

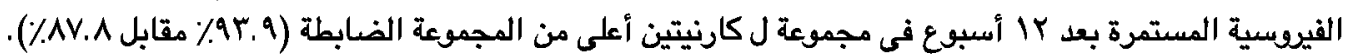

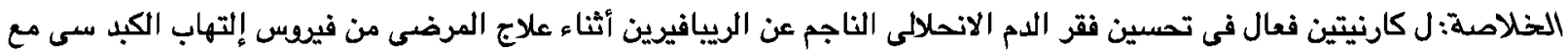
زيادة التزام المريض بالعلاج الذى يضمن أفضل فرصة لتحقين التحقيق الاستجابة الفيروسية المستمرة. 